\title{
CONTENTS
}

Contents

The Legacy of Democratic Burden

Ellyne Dwi Poespasari

The Position of Mamak Kepala Waris in High Ancestral Inheritance in Minangkabau Indigenous Community

Laina Rafianti, Ahmad M. Ramli \& Rika Ratna Permata

Promoting Traditional Cultural Expressions via YouTube

Sudjito \& Mohammad Paurindra Ekasetya

Controling the Abandoned Land in Tegal Regency

Lastuti Abubakar \& Tri Handayani

Juridical Implications of The Sustainable Finance Principles Implementation in the Banking Sector on the Obligations of Sustainable Reporting

Yossie M. Y. Jacoba, Ishak Alfred Tungga \& Umbu Lily Peku Wali

Intervention of Intellectual Property Rights on Household Industry Productivity

Djernih Sitanggang \& Efa Laela Fakhriah

Disparity of the Waiting Period of the Capital Punishment Execution for Narcotics and Murder Cases in the Perspective of Human Rights

Hamsir, Zainuddin \& Abdain

Implementation of Rehabilitation System of Prisoner for the Prisoner Resocialization in the Correctional Institution Class II A Palopo

Hamja

Effectiveness of Mental Development of Prisoners in Cirebon Narcotics Prison Class IIA as a Form of Correctional Purposes

Suparto \& Admiral

The Existence of Party Court in Completing the Internal Disputes of Political Parties in Indonesia (A Case Study of Persatuan Pembangunan Party)

Mety Rahmawati

Indonesian Worker Protection from Labour Exploitation in Singapore

$169-185$

Sonny Dewi Judiasih, Nazmina Asrimayasha \& Luh Putu Sudini

Prohibition of Intera Religion Marriage in Indonesia

189-203

Suwari Akhmaddhian

Citarum Authority Agency as the Commitment of the Government in the Conservation of Water Resources to Realize the System of Environmental-Based Water Management

Agus Suharsono

Harmonizing the Settlement of Authority Dispute Between Government Institutions in Indonesian Tax Law

Fajar Pratama

Legal Politics Aspect of Regulation, Efforts of Safeguard, Supervision, and Control Over the Comercial Explosives in Indonesia

Nyndya Fatmawati Octarina \& Hardianto Djanggih

Legal Implication of Black Campaigns on The Social Media in The General Election Process

Name Index

Subject Index 


\section{The Legacy of Democratic Burden}

Simultaneous general elections held on April $17^{\text {th }} 2019$ will enter a new phase, it is an open campaign. The actual excesses that have occurred long before the open campaign began. Attacking each other between candidates - both presidential and deputy candidates, as well as prospective legislative members has revealed its action through electronic media. Campaigners from each party have also issued movement to defend their hero and program, as well as personal vices and their image.

There are several interesting things in this election and become a tendency that is difficult to change for the future, even though this is not impossible. First, voters still rely on figures without examining the candidate's achievements thoroughly. It can be viewed in the presidential and vice presidential elections. The blind love covered the truth and caused unable to see, hear, or look for other truths presented by the opposing campaign team. This is probably what often voters in Indonesia called as immature in managing themselves and the information presented in front of them. In an era of openness, where access is wide open, this attitude is counterproductive in democratic life.

Second, there is still crowded money politics in the lower classes, especially for legislative elections. The rise of this attitude cannot be separated from the behavior of members or candidates and also the behavior of the community. Previously, elected legislators do not contribute anything to their constituents and only taking care of themselves or their parties. This attitude causes constituents to think of obtaining benefits up front by requiring candidates to give some money or goods if they want their votes. This condition seems to be a good symbiosis relationship at the beginning, but it's bad at the end.

Third, it is the effect of the two or perhaps more of the mentioned circumstances above that cause democracy in our country called as pseudo democracy. Democratic prerequisites that expect a healthy process and selection are not achieved. The process is full of tricks and intrigue, candidates who do not follow such a process will be crushed. This process does not cause people to become politically aware and healthy, but reinforce the notion that politics is dirty.

Democracy is expensive, and it is become useless if the expensiveness of process cannot produce qualified executive and legislative. This nation will pay more in the future caused of present democratic condition. This will not make lighter, but will increasing to the burden on our children and grandchildren. Then, where is the love for posterity if it turns out that only the burden is given by us?

As time running - like democracy - the Jurnal Dinamika Hukum also made changes by giving the author opportunity to express his thoughts more deeply. This change is a manifestation of democracy principles, namely freedom of expression, with no more page restrictions. May this change bring goodness. 